Beethoven's Piano Sonatas 



\title{
Beethoven's Piano Sonatas
}

A Short Companion

\section{Charles Rosen}

\author{
Yale University Press \\ New Haven and London
}


Copyright (C) 2002 by Charles Rosen

All rights reserved. This book may not be reproduced in whole or in part, in any form (beyond that copying permitted by Sections 107 and 108 of the U.S. Copyright Law and except by reviewers for the public press), without written permission from the publishers.

For information about this and other Yale University Press publications, please contact: U.S. Office: sales.press@yale.edu www.yalebooks.com

Europe Office: sales@yaleup.co.uk www.yalebooks.co.uk

Set in Ehrhardt by Fakenham Photosetting Ltd, Norfolk

Printed in Great Britain by the MPG Books Group

ISBN 978-0-300-09070-3 (hbk.)

Library of Congress Control Number 2001093745

A catalogue record for this book is available from the British Library.

10987654

Published with assistance from the Annie Burr Lewis Fund. 
To the piano students in the summer school at the Pontina Festival at Sermoneta 
